\title{
Prediction of Carrying Capacity and Settlement of Geotextile Encapsulated Stone Columns
}

\author{
Tahar Ayadat* \\ Department of Civil Engineering, Prince Mohammad Bin Fahd University, Saudi Arabia
}

Submission: May 2, 2018; Published: June 12, 2018

*Corresponding author: Tahar Ayadat, Department of Civil Engineering, Prince Mohammad Bin Fahd University, P.O. Box 1664, Al-Khobar 31952, Saudi Arabia, Email: tayadat@pmu.edu.sa

\begin{abstract}
Stone columns are mainly used as a technique for improving the strength and consolidation characteristics of compressible soils. Several research works were performed in the laboratory and the field in order to study the performance of stone columns reinforced internally and/ or externally by geofabric. Nevertheless, very limited works investigated the application of the stress-deformation response of such a reinforced composite to predict the carrying capacity and settlement of reinforced stone columns. In the present investigation a triaxial testing program was carried out on Leighton Buzzard sand encapsulated in non-woven fabrics of different tensile strength, under different confining pressure. The tests were conducted in order to study the stress-strain behavior and deformation characteristics (mainly the elastic modulii) of the sand composites. Moreover, the results obtained were used to develop new models for predicting the carrying capacity and settlement of geotextile encased stone columns. For the bearing capacity model, the concept of the equivalent confining pressure geotextile/surrounding soils was employed; whereas, the concept of the equivalent stiffness or modulus of elasticity of the composite was used for the settlement model.
\end{abstract}

Keywords: Carrying capacity; Settlement; Encapsulated; Stone columns; Geotextile

\section{Introduction}

Stone columns are mainly used as a technique for improving the strength and consolidation characteristics of compressible soil. Several research works were performed in the laboratory and the field in order to study the performance of stone columns reinforced internally and/or externally by geofabric. Internal reinforcement was provided by insertion of fabric layers or meshes within the column; external, by simultaneous encapsulation in a geotextile (among others, [1,2]). Likewise, numerous numerical and theoretical investigations were performed on this subject, and many models were developed for predicting the bearing capacity and the settlement of the reinforced stone columns (among others $[3,4])$. However, very limited works investigated the application of the stress-deformation response of such a reinforced composite to predict the carrying capacity and settlement of reinforced stone columns.

In the present investigation a triaxial testing program was carried out on Leighton Buzzard sand encapsulated in non-woven fabrics of different tensile strength, under different confining pressure. The tests were conducted in order to study the stressstrain behaviour and the deformation characteristics (mainly the elastic modulii) of the sand composites. Moreover, the results obtained were used to develop new models for predicting the carrying capacity and settlement of geotextile encased stone columns. For the carrying capacity model, the concept of the equivalent confining pressure geotextile/surrounding soils was employed; whereas, the concept of the equivalent stiffness or modulus of elasticity of the composite was used for the settlement model.

\section{Experimental Investigation}

Conventionally, the determination of the axial strain of a triaxial sample is based on external measurement of displacement which includes a number of extraneous movements such as, load cell deflexion, top cap sample reorientation, top and base bedding and loading system deflexion. The simplest improved method to reduce the effect of these errors is to apply two or three loadunload cycles to the sample during the testing stage [5]. The Young's modulus is derived only from the second or subsequent loading curves. In the present work, this technique was used in order to determine the moduli of elasticity of sand samples unconfined and confined by non-woven fabrics.

The triaxial cell used was of a conventional design, as originally described by [6]. The back pressure and cell pressure were connected to air-water cylinders. The pressure source was compressed air connected to each cylinder via a regulator. The cell had an extended loading ram fitted with an internal load cell. The requirements of the tests lead to the use of a controlled stress system. A dead weight loading system with 3:1 lever arm was 


\section{Civil Engineering Research Journal}

designed. The maximum axial load on the specimen was estimated to be $8.85 \mathrm{kN}$. The load cell employed for load measurements was an Imperial College type and it had a capacity of $27 \mathrm{kN}$. To measure the vertical displacement of the triaxial samples, a linear variable differential transformer (LVDT) of a range of $50 \mathrm{~mm}$ was used. Pressure transducers were used to measure the cell pressure and the pore water pressure. Automatic volume change units developed at Imperial College of a capacity of $100 \mathrm{~cm}^{3}$ each were employed. The movement of the piston caused by the water flowing into or out of the top chamber, sealed by one bellofram, being measured by a displacement transducer mounted on the outside of the cylinder. A data acquisition system was used to record automatically the changes in the dimensions of the sample, the pore water pressure, axial loads, volume changes, etc.

A series of tests were carried out on Leighton Buzzard sand, which formed the sand column, not encapsulated and encapsulated in T700, T1000, T1500, and T2000 in order to determine the stress-strain curves of the composite, and then the modulus of elasticity of the composite and the axial stress at failure. The series was divided into five groups composed of 3 tests each. Each group corresponded to a single type under three different cell pressures of 40,80 , and $120 \mathrm{kPa}$. All the tests were carried out under cycling loading. The properties of Leighton Buzzard and the different geofabric are summarized in [1].

\section{Test Results}

A prototype of the stress-strain characteristics of the sand columns confined by T700, T1000, T1500 or T2000 under a cell pressure of $80 \mathrm{kPa}$ are presented in Figure 1. The resulting curve obtained from test on sand column without confinement is also included. This figure shows the effect of confining the specimens by different geofabric strengths under the same cell pressure. In comparison it seems that, there is no significant difference in the general trend of these curves apart from the decreasing rate of strain for a given stress with the increase of sand column rigidity as the column approaches its ultimate stress. It is clear that the increase of the strength of the geotextile resulted in a better performance of these sand columns under applied stress. For a given specimen, the vertical stresses at failure and the elasticity modulii increase with the tensile strength of the geotextile. Furthermore, a glance at the initial parts of these graphs indicates that the increase in geotextile's strength resulted in an increase in the 'linearity' of these parts, indicating that the deformation behavior of the columns transformed from bulging columns to compressible piles. Figure 2 shows a prototype on the effect of the confining pressure on strain-strain characteristic of specimens encapsulated by the same geofabric T1000. It is clear from this Figure that for a given strain, the stress increases with the increase in the confining pressure.

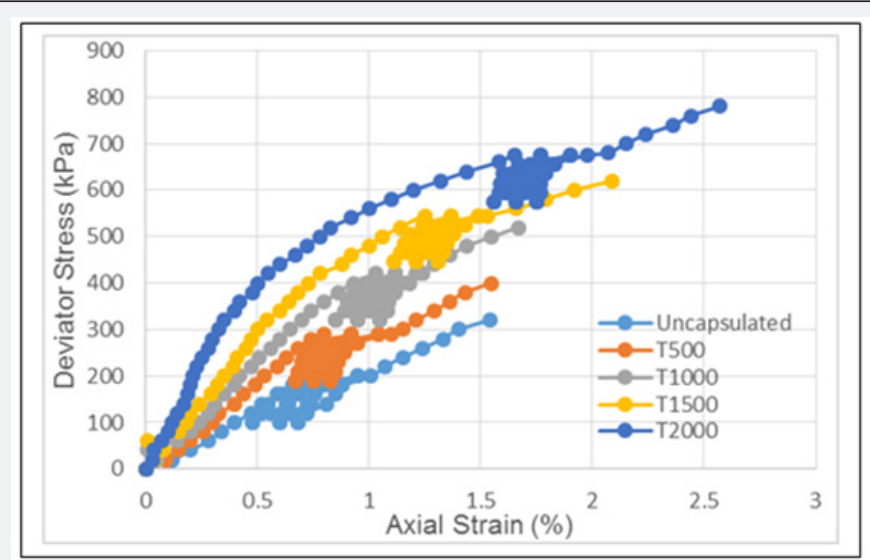

Figure 1: Stress-strain behaviour of saturated LBS specimens confined and not confined by 'Terram' (cell pressure $=80 \mathrm{KPa}$ ).

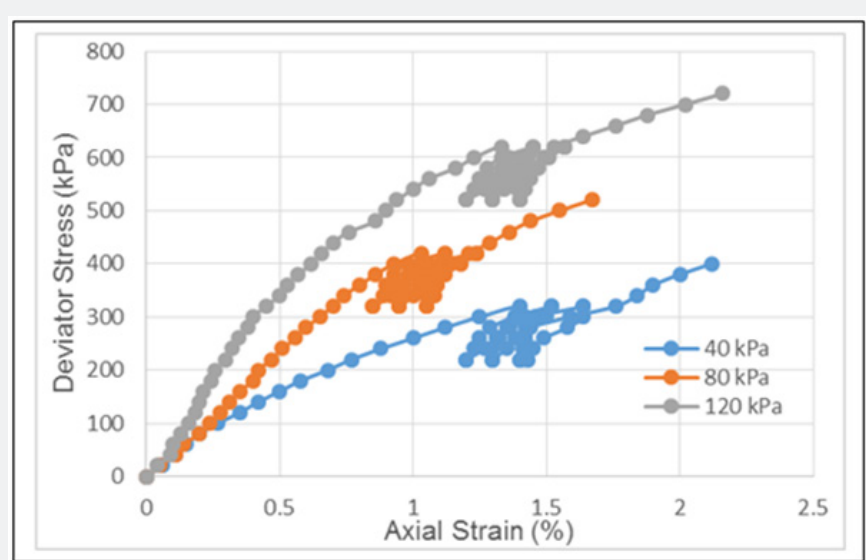

Figure 2: Stress-strain behaviour of saturated LBS specimens confined by T1000 under three different cell pressures. 


\section{Civil Engineering Research Journal}

Since no distinct indication of failure could be observed from these graphs, Chin's stability method was used to predict the ultimate carrying capacity of these sand columns. For all the performed tests, Chin's stability plot [7] was used to determine the ultimate carrying capacity of the sand columns. This method assumes that the stress-strain curve of the column when the load approaches the failure load is of a hyperbolic form, and the plot of the ratio of strain of the column $(\varepsilon)$ to the stress applied on its top $(\sigma)$ against an abscissa of the strain of the column $(\varepsilon)$ is linear. The inverse slope of this line would therefore give the ultimate carrying value of the column. As expected, Chin's stability plots for these tests consisted roughly of successive straight lines, which is the characteristic of Chin's plot, but with slight difference in their slopes. Because of the slight difference between the slopes of the successive lines, it was considered that the stability plot for each test followed a straight line from the beginning of the test. In Table 1 the ultimate deduced carrying capacities of the different sand columns are given. Moreover, the variation of the ultimate carrying capacity of these columns with geotextile's strength is presented in Figure 3. It is confirmed from this figure that the ultimate carrying capacities of the columns' increased with increase in their rigidity.

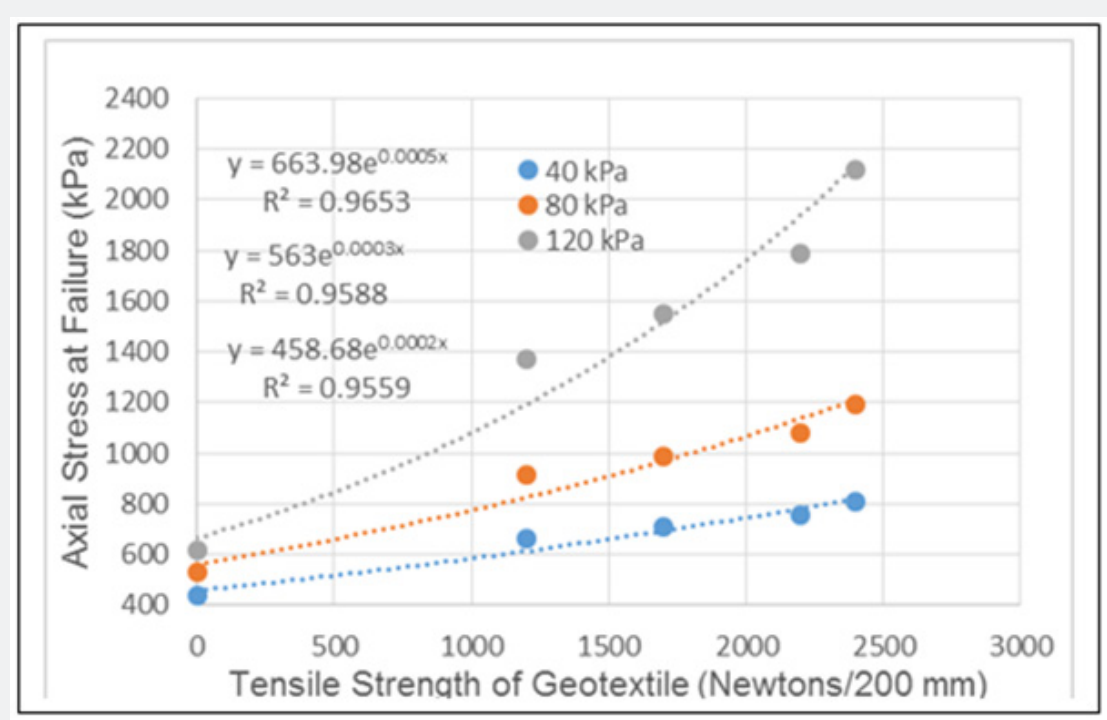

Figure 3: Variation of axial stress at failure with geotextile tensile strength of Terram.

Table 1: Ultimate carrying capacities (kpa) of the different sand columns.

\begin{tabular}{|c|c|c|c|}
\hline \multirow{2}{*}{ Sand Columns } & \multicolumn{3}{|c|}{ Triaxial Cell Pressure } \\
\cline { 2 - 4 } & $\mathbf{4 0 ~ k P a}$ & $\mathbf{8 0 ~ k P a}$ & $\mathbf{1 2 0} \mathbf{~ k P a}$ \\
\hline Not Encapsulated & 400 & 455 & 500 \\
\hline T500 & 625 & 833 & 1250 \\
\hline T1000 & 667 & 909 & 1429 \\
\hline T1500 & 714 & 1000 & 1667 \\
\hline T2000 & 769 & 1111 & 2000 \\
\hline
\end{tabular}

As mentioned in the previous section, because of the sand grading (coarse) and the presence of the geofabrics, the determination of the modulus of deformation using conventional tests leads, to some extent, to underestimated values. For this reason an improved method using cyclic loading was used to reduce the errors based upon the external measurement of strain. The modulii of elasticity of all the specimens derived from the second loading curves are presented in Figure 4 and summarized in Table 2. All the values were obtained from considering the secant modulii. Figure 4 shows that for a given specimen, the elasticity modulii increase with the tensile strength of the geotextile. Moreover, as expected the modulus of elasticity of sand encapsulated by a geofabric definitely is a function of confining pressure.

Table 2: Modulus of elasticity (kpa) of the different sand columns.

\begin{tabular}{|c|c|c|c|}
\hline Sand Columns & \multicolumn{3}{|c|}{ Triaxial Cell Pressure } \\
\hline & $\mathbf{4 0 ~ k P a}$ & $\mathbf{8 0 ~ k P a}$ & $\mathbf{1 2 0} \mathbf{~ k P a}$ \\
\hline Not Encapsulated & 18980 & 28760 & 36685 \\
\hline T500 & 36300 & 55030 & 70190 \\
\hline
\end{tabular}




\section{Civil Engineering Research Journal}

\begin{tabular}{|c|c|c|c|}
\hline T1000 & 45100 & 68360 & 87185 \\
\hline T1500 & 55660 & 84370 & 107605 \\
\hline T2000 & 73060 & 110730 & 141230 \\
\hline
\end{tabular}

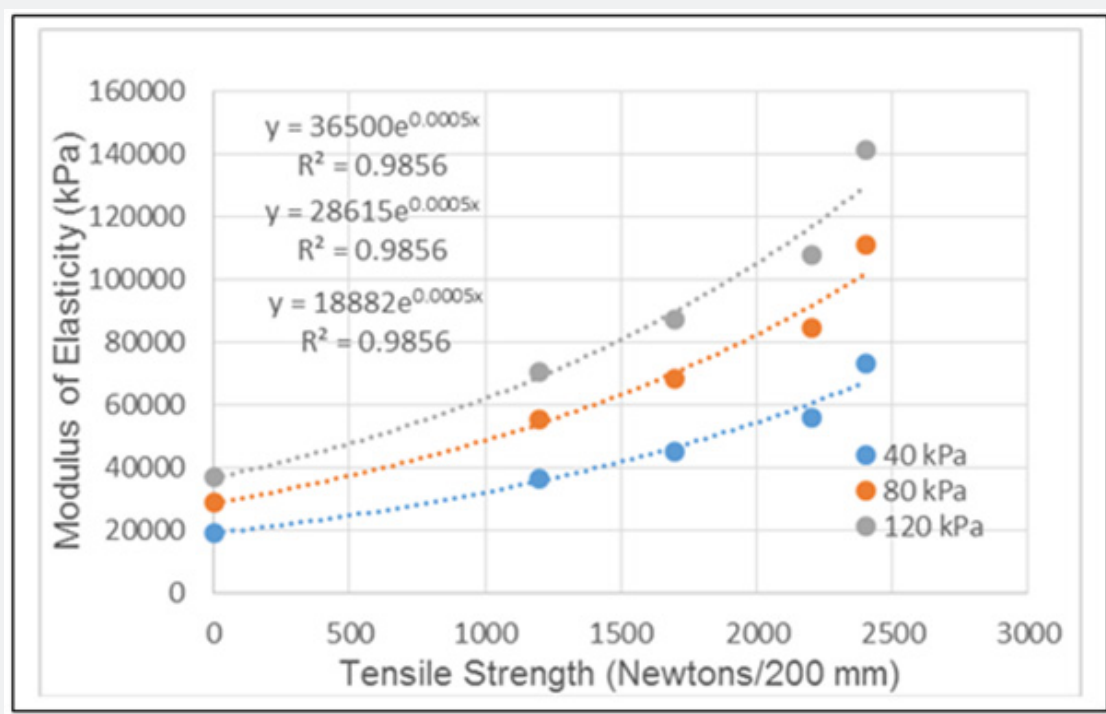

Figure 4: Variation of Modulus of Elasticity with geotextile tensile strength of Terram.

\section{Theoretical Development}

Based on the triaxial testing results, it is confirmed that the reinforced stone column concept is a better alternative to the stone column alone. In the latter method a combined system of compacted, granular columns in a matrix of native soil supports a vertical load which is transmitted through a rigid footing. The load is transferred and concentrated initially on the compacted granular cylinders or stone columns. The cylinders tend to dilate under this increased load and exert a lateral stress on the native, surrounding soil; but this lateral stress (and dilation) is resisted by passive earth pressure. This interaction is repeated until a state of equilibrium is reached. The rigidity and load carrying capacity of the columns depends largely upon the amount of lateral restraint or confining stress that can be mobilized in the surrounding soil. However, in the reinforced stone column concept, lateral restraint comes not only from the surrounding soil but also from the encapsulating fabric. The increase in confining stress induced by the fabric may equal or exceed the restraint provided by earth pressure from the surrounding soil. The fabric inhibits the development of internal tensile strains in the soil and develops tensile stresses. The composite soil-fabric system will develop overall smaller deformations for any particular load or larger load carrying capacity at any given deformations than the soil alone.

As mentioned previously, the results obtained by the triaxial testing program were used to develop new models for predicting the bearing capacity and settlement of geotextile encapsulated stone columns. For the bearing capacity model, the concept of the equivalent confining pressure geotextile/surrounding soils was employed; whereas, the concept of the equivalent stiffness or modulus of elasticity of the composite was used for the settlement model.

\section{Carrying capacity}

The carrying capacity of an encapsulated stone column depends mainly on the lateral restraint or confining stress that comes from the surrounding soil and the encapsulating fabric, which is noted in this investigation as the concept of the equivalent confining pressure geotextile/surrounding soil. $[8,9]$ stated that the granular material in the circular column is confined by radial stress just as though the column was in a triaxial apparatus. When load is applied from a spread footing, it tends to concentrate on the column as the stronger element of the composite. The column dilates and applies lateral stress to the surrounding clay which is resisted by passive pressure. The load capacity of the column is then controlled by the passive resistance of the soft soil and the maximum carrying capacity will rise when the ratio of the principal stresses is also a maximum depending upon the angle of friction of the column material $[10,11]$. It is well established that the carrying capacity of a stone column can be determined using the following equations (Equations 1 to 3 ):

$$
\begin{aligned}
q_{u} & =\tan \left(\frac{\pi}{4}+\frac{\varphi_{c}}{2}\right) \times \sigma_{r}^{\prime} \\
\sigma_{r}^{\prime} & =4 c_{u}+\sigma_{r 0}^{\prime} \\
q_{\text {all }} & =\frac{\tan \left(\frac{\pi}{4}+\frac{\varphi_{c}}{2}\right)}{B}\left(4 c_{u}+\sigma_{r 0}^{\prime}\right)
\end{aligned}
$$


Where:

$F S$ = factor of safety (1.5 to 2),

$c_{u}=$ undrained shear strength of the clay,

$\varphi_{c}=$ angle of shearing resistance of the column's material,

$\sigma_{r}^{\prime}=$ effective radial stress provided by the surrounding soil,

$\sigma_{r 0}^{\prime}=$ effective radial stress as measured by a pressuremeter $\left(» 2 c_{u}\right)$.

The carrying capacity of a stone column encapsulated in a geofabric can be predicted using equation (1). However, the effective radial stress $\sigma_{r}^{\prime}$ has to be determined by using the concept of the equivalent confining pressure. In this case, the effective radial stress, noted $\overline{\sigma_{r}^{\prime}}$ depends not only on the confining pressure but also on the tensile strength of the geofabric (Figure 5). The different values of $\overline{\sigma_{r}^{\prime}}$ presented in this Figure were obtained by using the results of the triaxial testing program (i.e. the values of the ultimate carrying load grouped in Table 1) along with equation (1). The variation of the effective lateral stress $\overline{\sigma_{r}^{\prime}}$ with the tensile strength of the geofabric has the form of an exponential function, as follows:

$$
\overline{\sigma_{r}^{\prime}}=a_{1} \cdot e^{b_{1} \cdot \tau_{t}}
$$

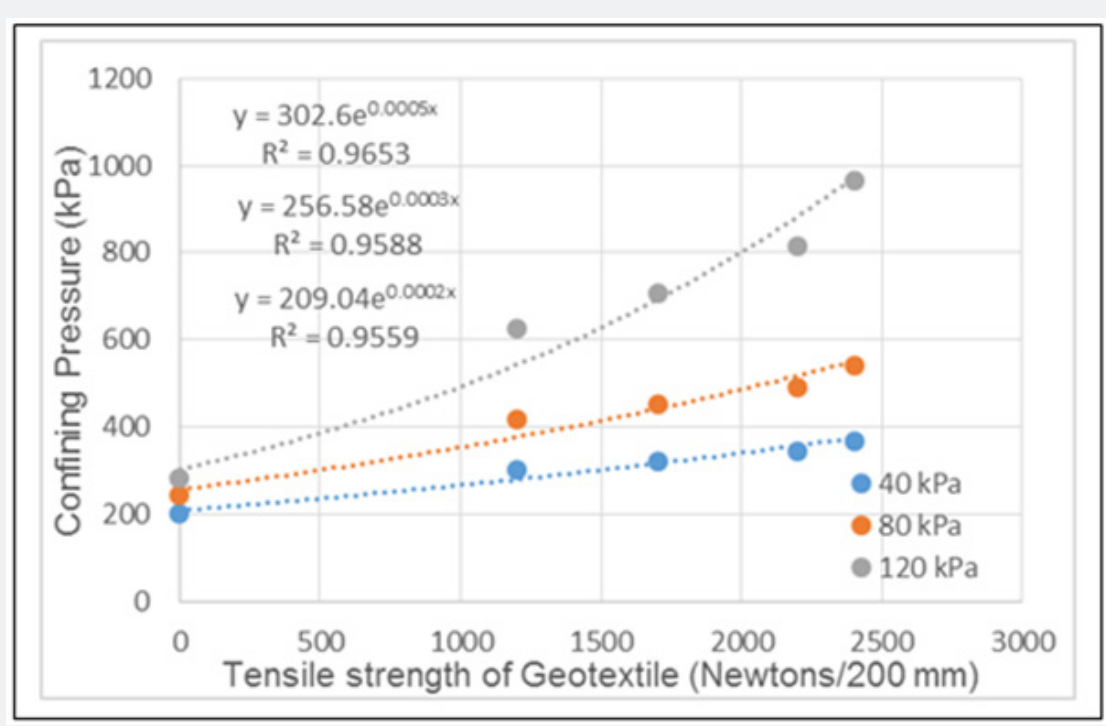

Figure 5: Variation of surrounding confining pressure with geotextile tensile strength of Terram.

\section{Where:}

$\tau_{t}=$ Tensile strength of the geofabric

$a_{1}$ and $b_{1}$ are parameters depending on the confining pressure as follows (the following expressions were deduced from graphical presentations):

$$
\begin{aligned}
& a_{1}=1.175 . \sigma_{r}^{\prime}+162.3 \\
& b_{1}=0.0001 \times e^{0.0115 \times \sigma_{r}^{\prime \prime}} \\
& \sigma_{r}^{\prime}=4 c_{u}+\sigma_{r 0}^{\prime} \approx 6 c_{u}
\end{aligned}
$$

So,

$q_{u}=\tan \left(\frac{\pi}{4}+\frac{\varphi_{c}}{2}\right) \times a_{1} \cdot e^{b_{1} \cdot \tau_{t}}$

With,

$$
\begin{aligned}
& a_{1}=7 c_{u}+162 \\
& b_{1}=10^{-4} \times e^{0.07 \times c_{u}}
\end{aligned}
$$

\section{Settlement}

For treatment of cohesive soils, stone columns are placed directly beneath the loaded footings in a grid pattern using either the wet vibro replacement method or the dry vibro displacement method. The columns may lie on the vertices of an equilateral triangle, a square or a regular hexagon (this last case is of limited practical importance). In order to reduce the complexity of the problem each domain is approximated by a circle of effective diameter $d_{e}$, the perimeter of which is shear-free, undergoes no normal displacement, and which has the same area as the actual domain [12]. The settlement of geotextile encapsulated stone columns can be estimated using the following expression:

$$
S_{\infty}=\frac{P \times L}{\overline{E_{c}} \times n_{2}}
$$

Based on the present results, and by applying the concept of the equivalent stiffness or modulus of elasticity of the composite, the modulus of elasticity of the stone columns encased in geofabrics is determined using the following relationships (Figure 6): 


\section{Civil Engineering Research Journal}

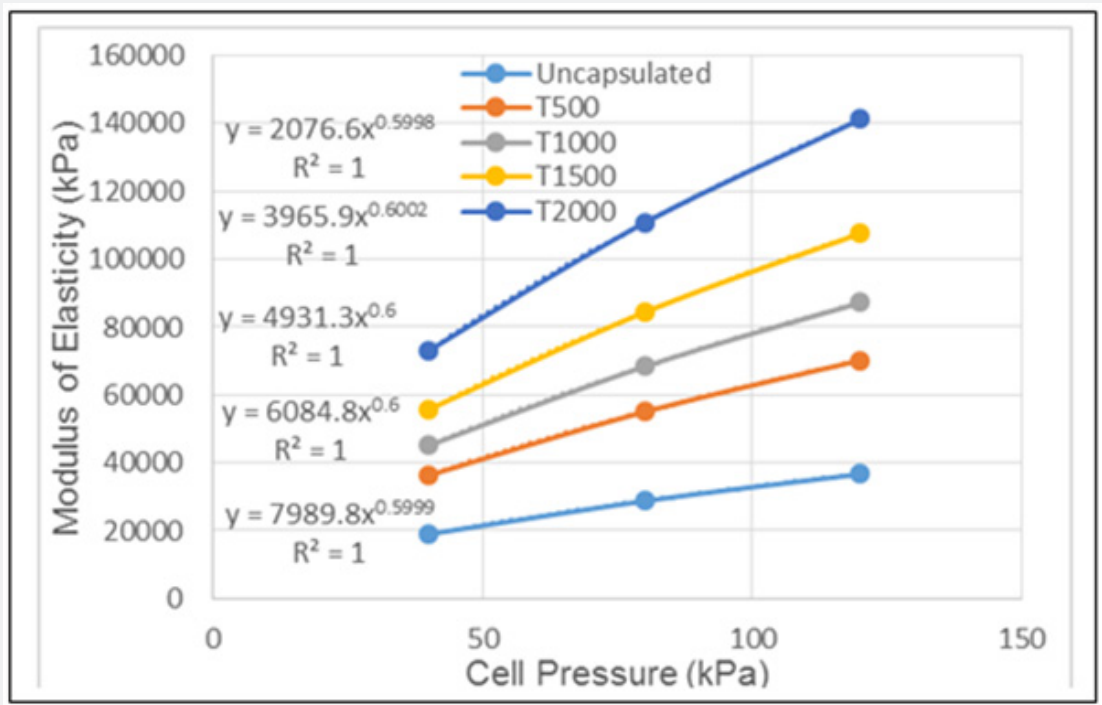

Figure 6: Variation of Modulus of Elasticity of the composite with triaxial cell pressure.

$$
\begin{aligned}
& \overline{E_{c}}=a_{2} \times\left(\sigma_{r}^{\prime}\right)^{0.6} \\
& \overline{E_{c}}=2.93 . a_{2} \times\left(c_{u}\right)^{0.6} \\
& a_{2}=2065 \times e^{5 \times 10^{-4} \times \tau_{t}}
\end{aligned}
$$

The factor $n_{2}$ can be computed using the equations developed by Priebe [13].

\section{Conclusion}

A triaxial testing program was carried out on Leighton Buzzard sand encapsulated in non-woven fabrics of different tensile strength, under different confining pressure. The tests were conducted in order to study the stress-strain behaviour and the deformation characteristics (mainly the elastic modulii) of the sand composites. Moreover, the results obtained were used to develop new models for predicting the carrying capacity and settlement of geotextile encased stone columns. The results obtained confirmed that the ultimate carrying capacities of the columns' increased with increase in their rigidity, Furthermore, they showed that the elasticity modulii increase with the tensile strength of the geotextile. As expected the modulus of elasticity of sand encapsulated by a geofabric definitely is a function of confining pressure.

\section{References}

1. Ayadat T, Hanna AM (2005) Encapsulated stone columns as a soil improvement technique for collapsible soil. Ground Improvement Journal 9(4): 137-147.
2. Ayadat T, Hanna AM, Hamitouche A (2008) Improvement of soft soil by stone column internally reinforced. Ground Improvement Journal 161(2): 55-63.

3. Etezad M, Hanna AM, Ayadat T (2013) Mode of failure of group of stone columns in soft soil. International Journal of Geomechanics (ASCE) 13(1).

4. Etezad M, Hanna AM, Ayadat T (2015) Bearing Capacity of Group of Stone Columns in Soft Soil. International Journal of Geomechanics (ASCE) 15(2)

5. Gorle D, Thijs M (1989) Geosynthetic-reinforced Granular Materials. $12^{\text {th }}$. ICSMFE, Rio de Janiero 1: 715-718.

6. Bishop AW, Henkel DJ (1962) The Measurement of Soil Properties in the Triaxial Test. Edward Arnold.

7. Chin FK (1972) The inverse Slope as a Prediction of Ultimate Bearing Capacity of Piles. Proc $3^{\text {rd }}$ Southeast Asian Conf on Soil Engng, Hong Kong, pp. 83-91.

8. Hughes JMO, Withers NJ (1974) Reinforcing of Soft Cohesive Soils with Stone Columns. Ground Engineering, pp. 42-49.

9. Schiosser F, Juran Y (1979) Parametres de Conception pour Sols Artificiellement Ameliores. Comptes Rendus du 7' Congres Europeen de Brighton 5: 227-252.

10. Greenwood DA (1970) Mechanical Improvement of Soils below Ground Surface. Proc ICE, pp. 11-22.

11. Mitchell JK, Katti RK (1981) Soil Improvement-State-of-the-Art Report. $10^{\text {th }}$ ICSMFE, Stockholm, pp. 261-317.

12. Balaam NP, Booker JR (1981) Analysis of Rigid Rafts Supported by Granular Piles. Inter J Num Meth in Engng 5: 379-403.

13. Priebe H (1976) Abschatzunz des Setzungsverhattens Elnes Durch Stopverdichtung Verbesserten Baugrundes. Die Bautechnik 53: 160162 
This work is licensed under Creative Commons Attribution 4.0 License DOI: 10.19080/CERJ.2018.05.555663
Your next submission with Juniper Publishers will reach you the below assets

- Quality Editorial service

- Swift Peer Review

- Reprints availability

- E-prints Service

- Manuscript Podcast for convenient understanding

- Global attainment for your research

- Manuscript accessibility in different formats

( Pdf, E-pub, Full Text, Audio)

- Unceasing customer service

Track the below URL for one-step submission https://juniperpublishers.com/online-submission.php 